\title{
Factors affecting the fishing impact on cartilaginous fishes in southeastern Spain (western Mediterranean Sea)
}

\author{
Manuel Mendoza ${ }^{1,2}$, Diego Garrido ${ }^{1}$, Jose M. Bellido ${ }^{1,3}$ \\ ${ }^{1}$ Instituto Español de Oceanografía, Centro Oceanográfico de Murcia, C/ Varadero 1, Apdo. 22, San Pedro del Pinatar, \\ 30740 Murcia, Spain. E-mail: mmendoza@ fulbrightmail.org \\ ${ }^{2}$ Current address: 'Rui Nabeiro' Biodiversity Chair, CIBIO, University of Evvora, Portugal. \\ ${ }^{3}$ School of Biological Sciences, University of Aberdeen, Tillydrone Avenue, AB24 2TZ Aberdeen, Scotland, UK.
}

\begin{abstract}
Summary: We propose a global index of impact based on the relative vulnerability of the local population of every species and the further application of regression trees globally optimized with evolutionary algorithms to study the fishing impact on the cartilaginous fish in southeastern Spain. The fishing impact is much higher in areas of less than $40 \mathrm{~m}$ depth within $11 \mathrm{~km}$ of the Cape Palos marine reserve. The impact also depends on the state of the sea and the kind of habitat. Deep-sea habitats associated with hard substrata and sandy beds show the highest impact, and sublittoral muds and habitats associated with circalittoral rocks with moderate energy show the lowest impact. The fishing impact changes throughout the moon cycle, showing different day-scale patterns associated with different habitats and different species compositions. Finally, we show that the global optimization of the regression trees can be essential to find some important patterns and that these trees are a useful tool for determining which areas are considered to be more important in terms of protection, taking into account specifically the vulnerability of the local populations.
\end{abstract}

Keywords: Cape of Palos MPA; conservation; cartilaginous fish; fishing impact; regression trees; evolutionary algorithms; vulnerable species.

Factores que afectan el impacto pesquero sobre peces cartilaginosos en el sureste español (Mediterráneo Suroccidental)

Resumen: Proponemos un índice global de impacto basado en la vulnerabilidad relativa de las poblaciones locales de cada una de las especies y la posterior aplicación de árboles de regresión globalmente optimizados con algoritmos evolutivos, para estudiar el impacto de la pesca en los peces cartilaginosos del sureste español. El impacto de la pesca es mucho mayor, dentro de los $11 \mathrm{~km}$ de la reserva marina de Cabo de Palos, en aquellas zonas de menos de $40 \mathrm{~m}$ de profundidad. El impacto también depende del estado de la mar y el tipo de hábitat. Los hábitats de aguas profundas asociados a sustrato duro y fondo arenoso muestran los máximos impactos, mientras que, tanto los fondos fangosos sublitorales como los hábitats rocosos circalitorales con moderada energía de las corrientes, muestran un menor impacto. Además, se dan cambios a lo largo del ciclo lunar en el impacto de la pesca, lo que significa que existen diferentes patrones diarios, asociados a distintos hábitats, con distinta composición específica. Finalmente, mostramos que la optimización global de los árboles de regresión es esencial para revelar patrones importantes y son una herramienta útil para determinar aquellas áreas mas importantes en términos de protección, teniendo en cuenta, concretamente, la vulnerabilidad de las poblaciones locales

Palabras clave: Área Marina Protegida de Cabo de Palos; conservación; peces cartilaginosos; impacto pesquero; árboles de regresión; algoritmos evolutivos; especies vulnerables.

Citation/Como citar este artículo: Mendoza M., Garrido D., Jose M. Bellido. 2014. Factors affecting the fishing impact on cartilaginous fishes in southeastern Spain (western Mediterranean Sea). In: Lleonart J., Maynou F. (eds), The Ecosystem Approach to Fisheries in the Mediterranean and Black Seas. Sci. Mar. 78S1: 67-76. doi: http://dx.doi.org/10.3989/ scimar.04025.21A

Editors: Jordi Lleonart and Francesc Maynou.

Received: September 30, 2013. Accepted: January 10, 2014. Published: March 28, 2014.

Copyright: () 2014 CSIC. This is an open-access article distributed under the Creative Commons Attribution-Non Commercial Lisence (by-nc) Spain 3.0. 


\section{INTRODUCTION}

Fishing is a major agent of disturbances to marine ecosystems (e.g. Watling and Norse 1998, Pauly et al. 2002, 2003, Kaiser et al. 2003) and in some extreme cases can even lead to extinctions of some marine specimens or populations (Dulvy et al. 2003). Fishing has caused a general decline in fish biomass and placed many marine species under serious conservation concern (e.g. Casey and Myers 1998, Pauly et al. 2002, Baum et al. 2003, Dulvy et al. 2003, Sadovy and Cheung 2003, Madsen 2007). According to a United Nations Food and Agriculture Organization (FAO) estimate, over $70 \%$ of the world's fish stocks are either fully exploited or depleted. Additionally, fishing disrupts food webs, leading to changes in the structure of marine habitats, influencing the diversity, composition, biomass and productivity of the associated biota (Jennings and Kaiser 1998).

In the Mediterranean Sea, fish stock levels are alarmingly low. The European Environment Agency reports that over $65 \%$ of all fish stocks in the region are outside safe biological limits, while the FAO considers that some of the most important fisheries are threatened. There are clear indications that catch size has declined, often dramatically, and in many areas larger and longer-lived species have disappeared entirely from commercial catches (Kaiser et al. 2003).

More specifically, cartilaginous fish have shown to be particularly vulnerable to fishing mortality resulting from direct fisheries as well as from by-catches. Sharks and rays are typical k-strategists. Most of their species show slow growth and delayed maturation, long reproductive cycles, low fecundity and long life spans. They generally occupy a high position in trophic food webs. Forty percent of their species are viviparous, and the egg-laying species deposit only a few large benthic eggs. Moreover, 55\% of skate species are endemic to single zoogeographic localities (McEachran and Musick 1975, Dulvy and Reynolds 2002). These characteristics make them especially vulnerable species, more likely to be affected by intense fishing activity than most teleosts (Castro et al. 1999, Stevens et al. 2000).

Cartilaginous fish are considered a priority in fishery research and management. In 1999, the FAO developed an International Plan of Action for the Conservation and Management of Sharks (IPOA-Shark); in 2003 the United Nations Environment Programme (UNEP) developed the Mediterranean action plan for cartilaginous fish; and in February 2009 the European Commission adopted the first ever EU Action Plan for the Conservation and Management of Sharks. The aim of the European Commission Plan is to ensure that effective steps are taken to help rebuild their stocks under threat, and to set down guidelines for the sustainable management of the fisheries concerned. The plan also includes measures to improve scientific knowledge of their stocks and fisheries. This study aims to provide a better understanding of the determining factors of fishing impact on cartilaginous fish in the western Mediterranean Sea and thus contribute to the objectives of this European Action Plan.
We study the impact of fishing on the cartilaginous fish by taking into account the vulnerability of the local populations of each species involved in the fisheries of the western Mediterranean Sea. Genetic diversity correlates strongly with the capacity of species to adapt to environmental changes (Frankham et al. 2002), so the protection of vulnerable populations is essential for the protection of the species.

Vulnerability has been categorized by the International Union for Conservation of Nature (IUCN) as the probability of becoming 'endangered', i.e. at risk of becoming extinct because the species in question is either few in numbers or threatened by changing environmental or predation parameters. In this survey, vulnerability is estimated taking into account only local abundance.

Vulnerability has been estimated using more complex criteria. The biological vulnerability score from Millsap et al. (1990), for example, was based not only on population size, but also on population trend, changes in distribution, fecundity, and ecological specializations. More recent studies have shown, however, that it is by no means straightforward to establish the vulnerability or risk of extinction of the species. Vulnerability has been shown to correlate with some biological attributes of the species, which are referred to as intrinsic vulnerability (Jennings et al. 1999, Reynolds et al. 2001, Dulvy et al. 2004, Castro et al. 2005, Frisk et al. 2005, Ferretti et al. 2008, Dulvy and Forrest 2010). Body size correlates with local extinction risk, perhaps due to its correlation with mortality and life-history parameters such as late age at maturity (Dulvy and Reynolds 2002). However, marine species cannot even be directly assumed as being less vulnerable on the basis of biological attributes such as high fecundity or large-scale dispersal characteristics (Dulvy et al. 2003). Isaac and Cowlishaw (2004) show that, in addition to body size, vulnerability can also depend on ecological flexibility, type of habitat and diet. They also found that species' vulnerability to different types of threat can be highly variable and is likely to depend on both threat type and biology. The vulnerability of a species can be quantified in many different ways and the vulnerability of a species is not the same as the vulnerability of some of its populations. Directly using local abundance and range of distribution is probably the most simple and straightforward way to evaluate the vulnerability of a population, and that is the approach taken in this study.

Many studies (e.g. Dulvy et al. 2004) have dealt with the impact of fishing, but not with the factors affecting the fishing impact on a whole taxonomical group, taking into consideration, moreover, the specific vulnerability of the population of each species. This study therefore proposes a new approach to analysing the impact of fishing, using in addition a novel methodological approach from the machine learning field. Regression trees allow for the recognition of patterns in data (Mendoza et al. 2010, 2011, Davidson et al. 2012). Here, these patterns are the combinations of technical, environmental and geographical factors that increase the fishing impact on cartilaginous fish in southeastern Spain. 
Table 1. - Numerical variables.

\begin{tabular}{|c|c|c|c|}
\hline Variable & Min & Max & Mean \\
\hline Impact (response variable) & 0 & 598.6 & 17.08 \\
\hline Vessel length (m) & 14 & 23 & 16.65 \\
\hline Vessel speed (knots) & 1.9 & 3.7 & 3.06 \\
\hline Course of the ship (degrees) & 0 & 360 & 109.87 \\
\hline Wind force (knots) & 0 & 8 & 1.84 \\
\hline Sea state (Douglas sea scale) & 0 (Calm) & 5 (Rough) & 1.18 \\
\hline Mean latitude (degrees) & 37.26 & 39.31 & 37.85 \\
\hline Mean longitude (degrees) & -1.65 & 1.87 & -0.44 \\
\hline Duration of the haul (hours) & 2.1 & 8.49 & 3.49 \\
\hline Mean depth (m) & 22 & 718 & 257 \\
\hline Slope of the sea bed (degrees) & 0 & 7.5 & 1.6 \\
\hline Bathymetry (m) & -815 & -22 & -221.50 \\
\hline Orientation of the sea bed (degrees) & 0 & 360 & 120.14 \\
\hline Distance to the Cape Palos marine reserve $(\mathrm{km})$ & 0.22 & 223 & 40 \\
\hline Distance to the coast $(\mathrm{km})$ & 1.76 & 60.06 & 19.4 \\
\hline Time (hours) & 3.81 & 14.62 & 9.79 \\
\hline Moon day $($ New Moon=1) & 1 & 30 & 15.34 \\
\hline
\end{tabular}

\section{MATERIALS AND METHODS}

The study area is southeast Spain (western Mediterranean Sea), extending from the area of Cartagena (Murcia, Spain) and the Gulf of Alicante to the vicinity of the island of Ibiza, between $37^{\circ} 15.6^{\prime}$ and $39^{\circ} 18.6^{\prime} \mathrm{N}$, and $1^{\circ} 39.0^{\prime} \mathrm{W}$ and $1^{\circ} 52.2^{\prime} \mathrm{E}$.

\section{The data}

Data were extracted from the Spanish Institute of Oceanography (IEO) observers' onboard database, from a fleet of 27 trawler boats, for the period 2006-2011. This data set includes the abundance of a number of species caught in the western Mediterranean Sea, as well as a variety of features relating to the haul, the fishery units, the vessels and the environmental and geographic information of the fishing trips, among other aspects. Some of these features were directly used as variables for the analyses. Other variables were obtained indirectly from them. The mean depth of the haul, its mean geographical coordinates, and the mean point time, for example, were obtained by averaging the start and end point values. Some other variables, such as the moon day, were obtained from the Internet. The slope and its orientation, the distance from the Cape of Palos marine protected area (MPA) and some variables related to the habitat were obtained from the mean coordinates of each haul, using a geographic information system (GIS) software. Only three technical variables were available for the full set of hauls, the vessel length and speed and the duration of the haul. This resulted in 16 numerical variables (Table 1) and 13 categorical variables (Table 2), which were used as predictors for the analyses.

Table 2. - Categorical variables. * Variables from the EUNIS Habitat Classification.

\begin{tabular}{ll}
\hline Variable & Categories \\
\hline Light & Day, Night \\
Target species & (1) European hake (Merluccius merluccius), (2) red shrimp (Aristeus antennatus), (3) Multispecies 1 (octo- \\
& pus, sparids, mullets, squid and sepiids), (4) Norway lobster (Nephrops norvegicus), (5) Multispecies 2 [deep- \\
& water pink shrimp (Parapenaeus longirostris), European hake, and blue whiting (Micromesistius poutassou)] \\
& and (6) Lophius and European hake \\
& January to December
\end{tabular}

Season

Substrate*

Substrate group plus*

Biozone*

Biozone Group*

Level 2 habitats*

Level 3 habitats*

Level 4 habitats*

EUNIS habitat*

Grouped*
January to December

Spring, summer, autumn, winter

Mud, sandy mud, sand, rock or other hard substrata

Muds, sands, rock or biogenic reef

Bathyal, deep circalittoral, infralittoral, upper circalittoral

Bathyal, shelf, shallow, shallow aphotic

Deep-sea bed, circalittoral rock and other hard substrata, sublittoral sediment

Deep-sea mud, deep-sea sand, atlantic and Mediterranean moderate energy circalittoral rock, sublittoral sand, sublittoral mixed sediments, sublittoral mud, deep-sea rock and artificial hard substrata

Mediterranean communities of bathyal muds, faunal communities on deep moderate energy circalittoral rock, infralittoral fine sand, Mediterranean communities of shelf-edge detritic bottoms, Mediterranean animal communities of coastal detritic bottoms, Mediterranean communities of coastal terrigenous muds, infralittoral fine mud, Mediterranean communities of muddy detritic bottoms, Mediterranean coralligenous communities moderately exposed to hydrodynamic action

Mediterranean communities of bathyal muds, facies of sandy muds with Thenea muricata, deep-sea sand, faunal communities on deep moderate energy circalittoral rock, infralittoral fine sands, Mediterranean communities of shelf-edge detritic bottoms, Mediterranean biocoenosis of coastal detritic bottoms, Mediterranean biocoenosis of coastal terrigenous muds, infralittoral fine mud, deep-sea rock and artificial hard substrata, Mediterranean biocoenoses of muddy detritic bottoms, Mediterranean coralligenous communities moderately exposed to hydrodynamic action

Substrate group plus-biozone group bathyal muds, bathyal sands, shelf rock or biogenic reef, shallow sands, shelf muds, shallow muds, bathyal rock or biogenic reef, shelf sands, shallow aphotic rock or biogenic reef 
Table 3. - Vulnerability of the local populations of the cartilaginous fish species, with the mean, median and first quartile of vulnerability of the 299 species caught in the area

\begin{tabular}{lc}
\hline Species & Vulnerability \\
\hline Centrophorus granulosus & 372 \\
Centroscymnus coelolepis & 372 \\
Dasyatis akajei & 372 \\
Dasyatis pastinaca & 372 \\
Galeorhinus galeus & 372 \\
Heptranchias perlo & 372 \\
Hexanchus griseus & 372 \\
Mustelus punctulatus & 372 \\
Pteromylaeus bovinus & 372 \\
Raja brachyura & 372 \\
Squalus acanthias & 372 \\
Myliobatis aquila & 186 \\
Oxynotus centrina & 186 \\
Chimaera monstrosa & 93 \\
Mean & 107.6 \\
Dalatias licha & 74.4 \\
Raja asterias & 74.4 \\
Raja montagui & 62 \\
Median & 41.3 \\
Torpedo marmorata & 21.9 \\
Mustelus mustelus & 16.9 \\
Raja clavata & 14.9 \\
Q1 & 10.1 \\
Etmopterus spinax & 2.9 \\
Galeus melastomus & 2.1 \\
Scyliorhinus canicula & 1.8 \\
\hline
\end{tabular}

Some of these variables, such as the moon day, are cyclic. However, the analyses considers all the numerical variables as linear, with a start and an end point, and this can hide significant patterns in these variables. To avoid this problem, each cyclic variable was reincluded in the analyses with all the possible start and end points. As explained below, the analysis technique used for this study selects those variables involved in the model, so redundant information is not a problem.

The variables related to the substrate and the habitat were obtained from the EUNIS Habitat Classification, whose description is available online in Davies et al. (2004). The rest of the variables are described in Tables 1 and 2. A total of 501 hauls were available, in which 23 species of cartilaginous fish were identified (Table 3). Some individuals, identified only at the level of genus, were not used for the analyses. The fisheries were multispecies and none of the cartilaginous fish were target species.

\section{The analyses}

An impact value was assigned to each of the 501 hauls, taking into account both the total number of cartilaginous fish species caught in that haul and the vulnerability of the local population of each of these species. The local vulnerability of species $i\left(V_{i}\right)$ is the inverse of the relative frequency of hauls in which it appears. Thus, $V_{i}=N / N_{i}$, where $N$ is the total number of hauls in which the most frequently caught species appears, and $N_{i}$ the number of hauls in which species $i$ appears. In this way, (i) the vulnerability of a given species $\mathrm{n}$ times less frequent than another is $\mathrm{n}$ times higher, (ii) the vulnerability of the most frequently caught species is 1 (the minimum) and (iii) the vulnerability of those species that appeared in only one haul is maximum. The impact value of each haul was then calculated by summing the local vulnerability values of all the species caught in that haul.

Abundance values were available but they were not used directly because they had been estimated from subsamples of the whole catch, and this results in unreliable estimates for sparse species. Thus, abundance was estimated from the frequency of hauls in which the species appeared. Frequency has been widely used as an estimation of abundance, given that it has been shown to be correlated with abundance for most organisms (e.g. Hergstrom and Niall 1990, Venier and Fahrig 1998, Nielsen et al. 2005, Borregaard and Rahbek 2010).

Although the impact of the hauls is obviously calculated using only the cartilaginous fish species, to estimate the relative local vulnerability we take into account all the fish species caught in the area, from all the taxonomical groups. This makes it possible to compare the vulnerability of the local populations of the cartilaginous fish in comparison with the rest of the fish species.

The impact value was calculated for the 501 hauls, which were used as training data for regression tree development, with the rest of the variables (Tables 1 and 2) as predictors. Like classification trees, regression trees work as an 'expert system' that learns inductively from the input of a series of samples or training data. These tree-based machine learning techniques are "white box" or "knowledge discovery" techniques (Quinlan 1985, Krzysztof et al. 2007, Mendoza 2007), and unlike in other methods such as neuronal networks (considered as a 'black box' technique), the product of the learning can be represented explicitly, in the form of trees.

Commonly used regression and classification tree methods build the model in a forward stepwise search. Beginning with the root node, which includes all samples in the training dataset, the best possible variable to split the node into two child nodes is selected. In order to find the best variable, the software checks all possible splitting variables, as well as all possible values of the variable to be used to split the node. In choosing the best variable, the program seeks to minimize the average impurity of the two child nodes, an indication of the relative homogeneity (the inverse of impurity) of cases in the nodes. Once a split is made, the routine is repeated for each group separately until an overlarge tree is grown, which is then pruned back to the desired size. The resulting branching tree is a set of if-then logical conditions (the splits), whose interpretation is straightforward (Mendoza 2007, Rogan et al. 2008, Mendoza et al 2011).

In forward-search recursive partitioning methods, splits are chosen to maximize homogeneity at the next step only. Each split is analysed independently of the subsequent splits, searching then only a small fraction of the global search space. This typically leads to a globally suboptimal solution. Although this approach is known to be an efficient heuristic, the results of these recursive tree methods are only locally optimal. An alternative way to search over the parameter space of trees is to use global optimization methods such as evolutionary algorithms. 
In this study, the analyses were first performed using recursive regression trees, with SPSS 17.0, and later repeated with globally optimized regression trees when the evtree package for R (Grubinger et al. 2011) was available. Evtree optimizes the trees with evolutionary algorithms. It works as follows: first, a user-specified number of trees is initialized with random split rules in the root nodes. Then, mutation and crossover operators are applied to modify the structure of the trees and the tests are applied in the internal nodes. After each modification step, a survivor selection mechanism selects the best candidate models. The quality of the trees is measured as a function of its misclassification and the complexity of the tree. The selected trees are then replicated until the original number of trees is restored and the next iteration starts. In this evolutionary process the mean quality of the population increases over time. The algorithm terminates when the quality of the best $5 \%$ of trees stabilizes for 100 iterations, but not before 1000 iterations. If the run does not converge, the algorithm terminates after a user-specified number of iterations. The tree with the highest quality according to the evaluation function is returned (Grubinger et al. 2011). Unlike other methodologies that use all the information supplied by the training set (e.g. neural networks), for methodologies such as classification or regression trees, which are able to select those variables involved in the model, redundant information is not a problem.

\section{RESULTS}

Six species of the 23 cartilaginous fish involved in this study show vulnerability values lower than the median of the 299 fish species caught in the area (41.3). Three of them are even included in the first quartile (10.1, Table 3). Eleven species, on the other hand, appeared in only one haul, so their vulnerability value is maximum.

According to the evaluation function of the evtree algorithm, when all the variables are included in the analysis, the tree shown in Figure 1 is the one with the highest quality. It involves only two variables and shows that the main determining factor is the distance from the Cape Palos MPA, although only in combination with the depth. There are only eight hauls in the tree of Figure 1 that took place above $42 \mathrm{~m}$ depth (depth $<42 \mathrm{~m}$ ), within $10.6 \mathrm{~km}$ of the Cape Palos marine reserve (node 3 ). Their mean impact (182.75) is more than 20 times the mean impact of the 39 hauls that were carried out over $10.6 \mathrm{~km}$, also above $42 \mathrm{~m}$ depth $(8.795$ node 4 ), and more than ten times the mean impact of the full set of hauls $(17.078, \mathrm{n}=501$, node 0$)$. The mean impact of the 108 hauls within of $10.6 \mathrm{~km}$ the Cape Palos marine reserve, deeper than $42 \mathrm{~m}$, is only 16.59 (not in the tree of Fig. 1), so this distance alone does not affect the fishing impact. However, depth by itself does affect the impact. Above $42 \mathrm{~m}$ depth the impact

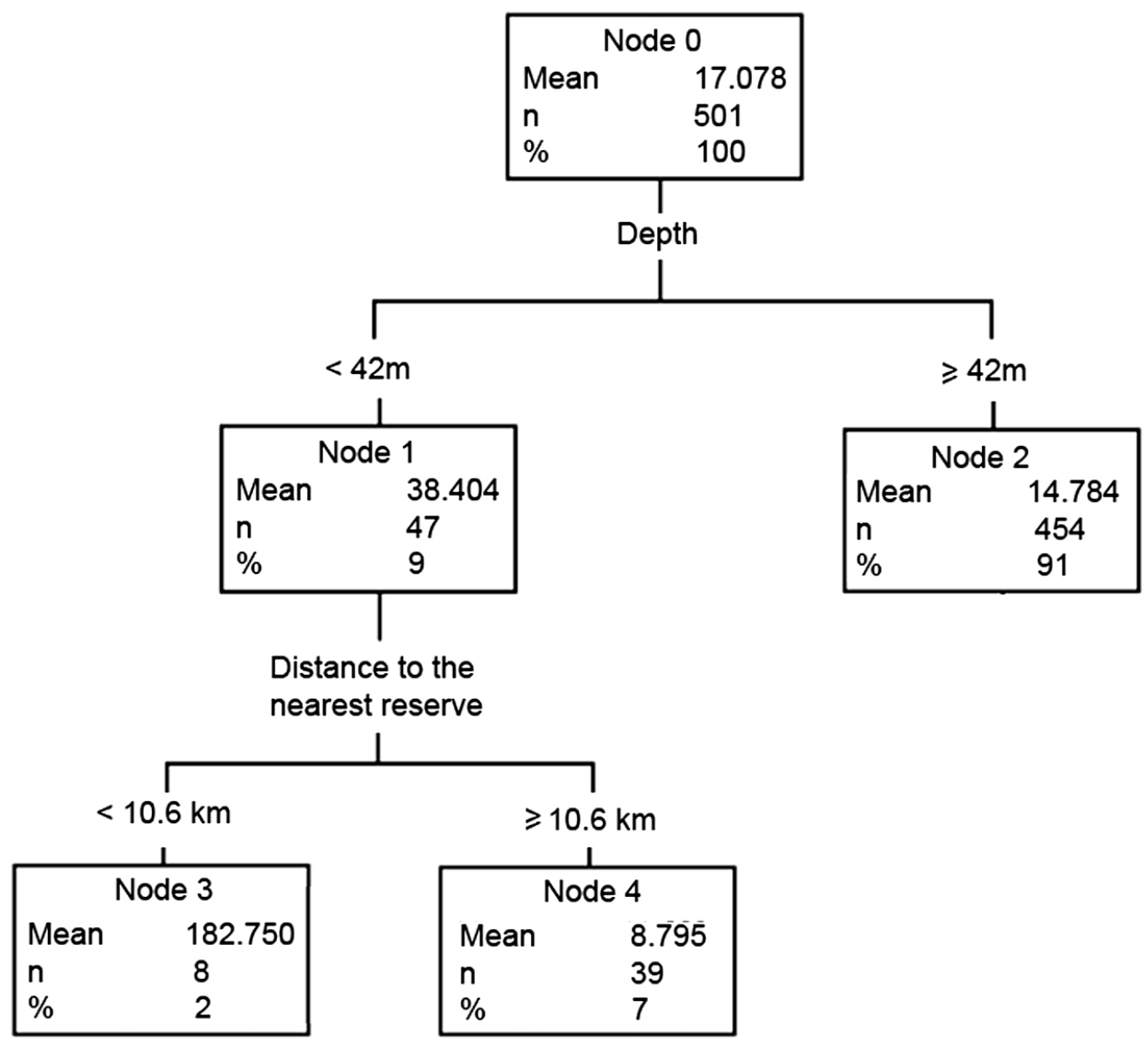

Fig. 1. - First tree selected by the evtree algorithm when all the variables are included in the analysis. 


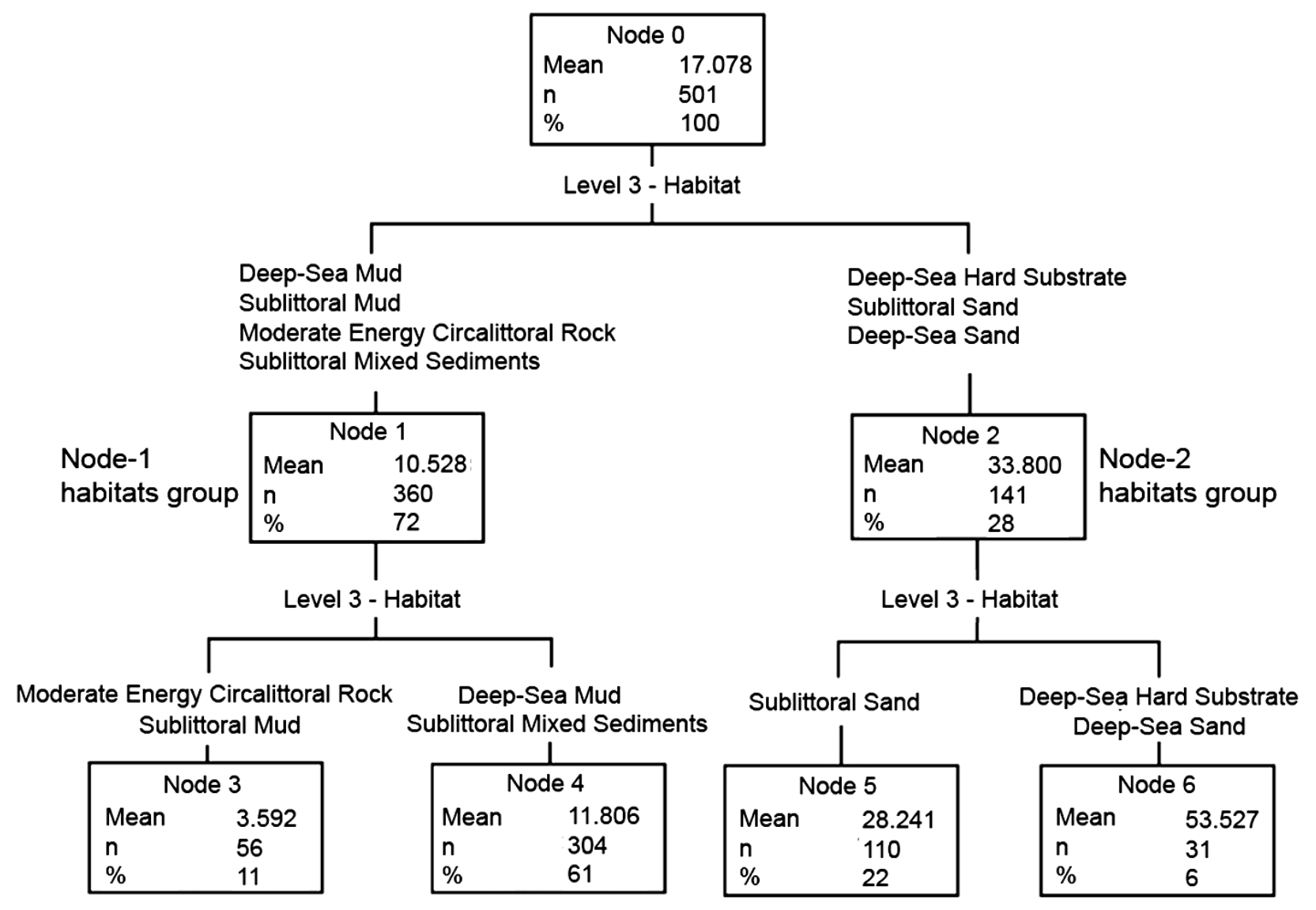

Fig. 2. - Tree obtained when only the variable Level 3-habitat is considered for the analysis. Node-1 and Node-2 habitats groups (see text).

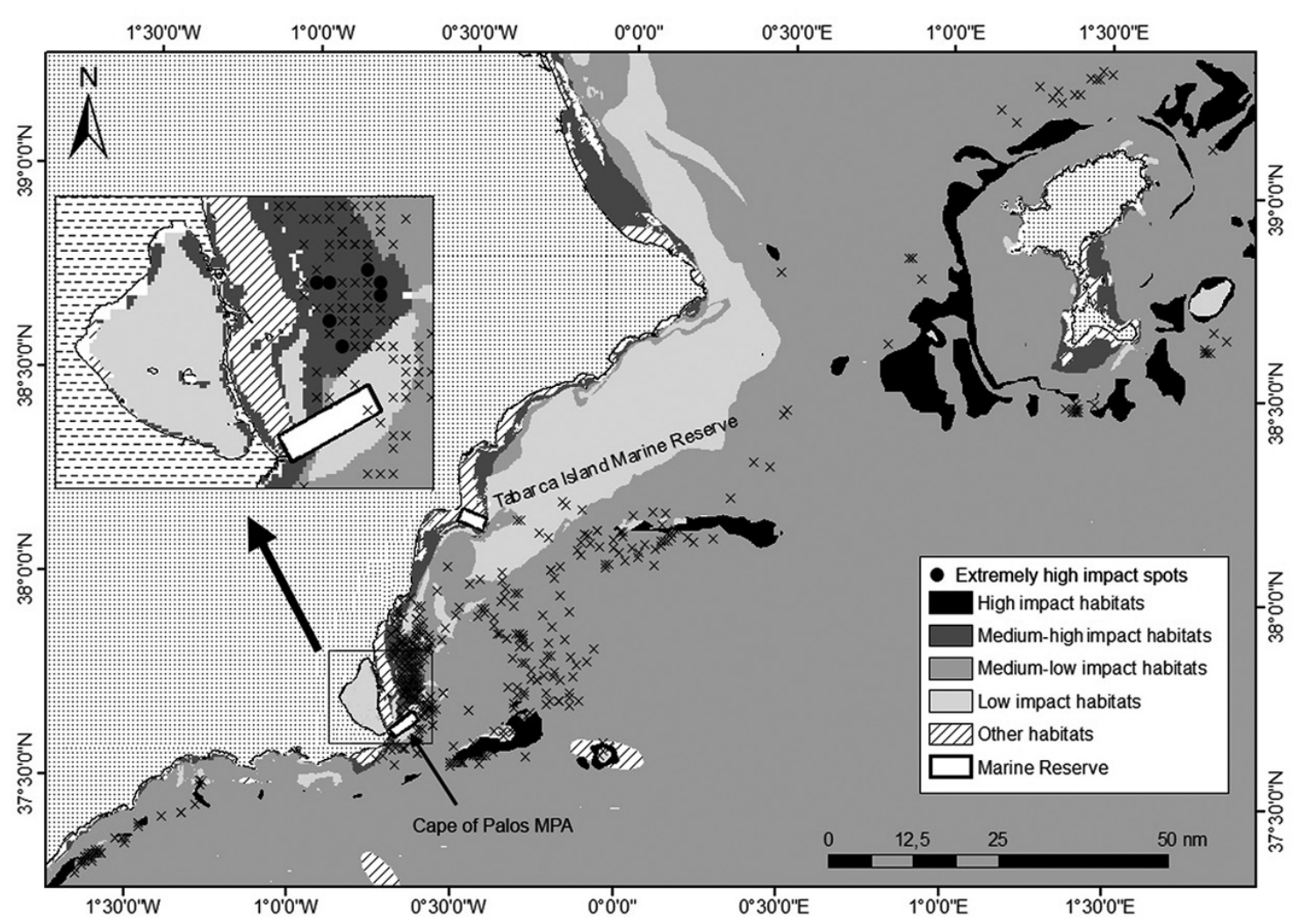

Fig. 3. - Impact level predicted according to the distance from the Cape Palos marine reserve, depth and type of habitat. 


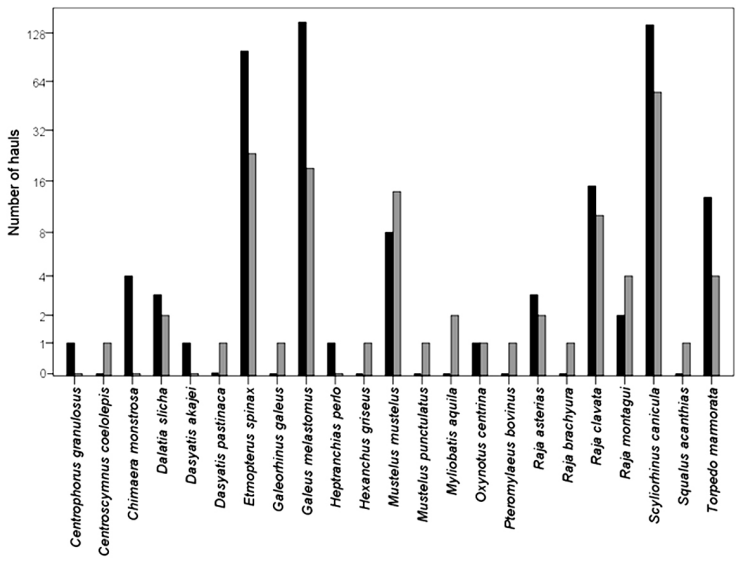

Fig. 4. - Abundance of hauls including each of the 23 species of cartilaginous fish (log scale) from node-1 (black columns) and node- 2 (grey columns) habitats groups (see text).

(38.40, $\mathrm{n}=47$, node 1 ) is 2.6 times higher than below (14.78, $\mathrm{n}=454$, node 2 ).

The tree shown in Figure 2 only includes the level3-habitat variable. The interpretation of this tree is straightforward. The mean value of impact for the 501 hauls (the full set) is 17.078 (node 0). The first splitting shows that the mean impact of the 360 hauls of the first group $(10.528$, node 1$)$ is less than a third of the impact of the 141 hauls of the second group (33.8, node 2 ). The 360 hauls of the first group (referred to hereafter as the node-1 habitats group) were carried out on deep-sea or sublittoral mud, in the vicinity of moderate energy circalittoral rock, or on sublittoral mixed sediments. The 141 hauls of the second group (referred to hereafter as the node- 2 habitats group), on the other hand, took place on deep-sea hard substrate, sublittoral sand or deep-sea sand. The tree shown in Figure 2 makes it possible to attribute a mean impact to each of these four groups of habitats, establishing a decreasing gradient from node 6 to node 3 .

Figure 3 shows a map representing the impact level predicted according to the distance from the Cape $\mathrm{Pa}-$ los MPA combined with depth, and type of habitat. The histogram shown in Figure 4 shows that the taxonomical composition of the node- 1 and node- 2 habitats groups differs widely.

The trend of the mean impact in the habitats of the node-2 habitats group throughout the full moon cy-

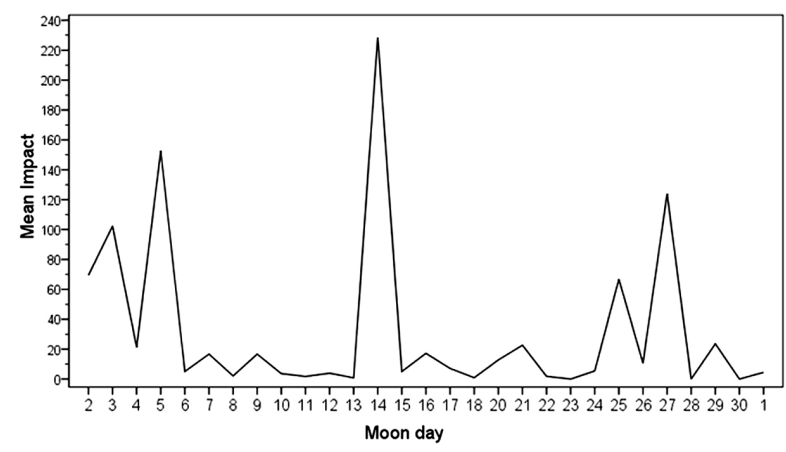

Fig. 5. - Evolution throughout the full moon cycle of the mean impact in the habitats of the node-2 habitats group (see text).

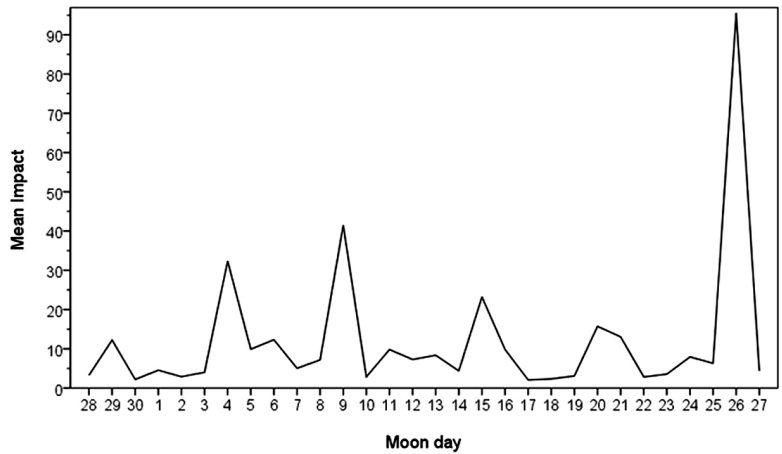

Fig. 6. - Evolution throughout a full moon cycle of the mean impact in the habitats of the node- 1 habitats group (see text).

cle can be seen in Figure 5. It shows a clear pattern of influence of the moon cycle in the fishing impact on the cartilaginous fish of this habitats group. This pattern was identified by a tree not shown here. The influence of the moon cycle on the fishing impact on cartilaginous fish from the four other kinds of habitat (node-1 group) was not identified by a regression tree. However, Figure 6 shows that there is also a very clear and intriguing pattern of influence characterized by six main peaks that are surprisingly well distributed every 5-6 days.

When the distance from the Cape Palos marine reserve and the kind of habitat are not considered for the analyses, a tree (not shown here) involving the variables state of the sea and depth is obtained. According to this tree, the state of the sea also affects the fishing impact, but only above $42.5 \mathrm{~m}$ depth. Below this depth the impact does not show significant differences with regard to the state of the sea. Above $42.5 \mathrm{~m}$ depth, however, the impact with smooth to rough sea (86.5, $\mathrm{n}=20$ ) is more than 36 times the impact with calm or rippled sea $(2.4, n=28)$. Depth by itself is also important. Independently of the rest of factors, above $42 \mathrm{~m}$ the impact is significantly higher than below.

When the analyses are performed without including any variables related to depth, habitat, substrate and state of the sea, no tree is obtained. This means that none of the rest of the variables have a significant effect on the impact, at least with the data available for this research.

\section{DISCUSSION}

Cartilaginous fish are generally considered sensitive and vulnerable species (e.g. Dulvy and Forrest 2010). However, some local cartilaginous fish populations in this study are far from being considered vulnerable, at least in comparison with the rest of the fish species from other taxa caught in the area. Six species of cartilaginous fish are less vulnerable than half of the 299 species caught in the area, and three of them even belong to the least vulnerable quartile. On the other hand, there are 13 cartilaginous fish species whose populations in the southeastern Spain (western Mediterranean Sea) can be considered highly vulnerable.

According to the results of the analyses with regression trees, the main determining factor of the fishing 
impact on the local populations of cartilaginous fish in the study area is the distance from the Cape Palos MPA, although only in combination with depth. The fishing impact is highest in those areas that are within $11 \mathrm{~km}$ (approx.) of the Cape Palos MPA, at less than $42 \mathrm{~m}$ depth. Under these conditions, the mean impact is more than 20 times the mean impact of the hauls that were carried out in other conditions.

The state of the sea also affects the impact. As in the case of the distance from the reserve, the state of the sea only affects it above a depth of around $42 \mathrm{~m}$ (the tree selected exactly $42.5 \mathrm{~m}$ ). Above that depth, when the sea has at least smooth wavelets (glassy or rippled), the impact is 36 times higher than with calm sea, when the impact is almost null.

Depth by itself is also important. Independently of the rest of the factors, above $42 \mathrm{~m}$ the impact is higher than below. Thus, there appears to be a threshold around this depth. Further research will be conducted in order to obtain a more detailed knowledge about the causes behind these finds.

The relationship between the impact and two combinations of factors, (1) depth and distance from the Cape Palos marine reserve, and (2) depth and state of the sea, could only be identified using globally optimized regression trees but not with recursive regression trees. With recursive trees, the variable depth is not selected as the first variable so the two variables distance from the Cape Palos MPA and state of the sea do not become significant and are not selected. This finding shows that, at least in some cases, the global optimization of the trees is fundamental.

The kind of habitat is also an important factor, especially at the level of two main groups of habitats. From the tree shown in Figure 2, it can be concluded that (1) habitats associated with hard substrata and sandy beds show a higher impact than those associated with mud or sublittoral mixed sediments, or ones that are in the vicinity of moderate energy circalittoral rocks, (2) the impact in sand is higher than in mud, (3) in both sand and mud the impact is higher on deep-sea than sublittoral bottoms, (4) in sublittoral areas the impact is higher in sand than in mixed sediments, and (5) the impact is higher in mixed sediments than in mud and also than in moderate energy circalittoral rocks.

This relationship of cartilaginous fish with depth and substrate is consistent with what is known about their ecology and ethology (Froese and Pauly 2011, Gouraguine et al. 2011, Pennino et al. 2013). Massutí and Moranta (2003), in addition, have shown that some assemblages of cartilaginous fish species are related to depth in the western Mediterranean, and Roel (1987) reached similar conclusions in Atlantic waters analysing the species separately. We show here that it is not only depth but also habitat, associated with depth and substrate, that affects the presence of cartilaginous fish. Machine learning has allowed us to show, in addition, that different kinds of habitat are associated with different degrees of impact and also how different kinds of habitat interact with other factors.

In sublittoral sands and deep-sea hard substrata and sand, the pattern of influence of the moon cycle is differ- ent than in habitats associated with muds or sublittoral mixed sediments, or in the vicinity of moderate energy circalittoral rocks. In both cases the temporal pattern is at day scale. The pattern of the first group (sublittoral sands and deep-sea hard substrata and sand) is mainly associated with the sublittoral sand habitat, whose 110 hauls make up the majority of the 141 samples of the group. This group shows an outstanding impact peak at full moon, isolated between two periods of 9 days of relatively low impact. This outstanding peak is clear in both the sublittoral and deep-sea sand habitats but not in the deep-sea hard substrata habitat (with only 11 hauls). At the other side of the moon cycle, from the $25^{\text {th }}$ to the $5^{\text {th }}$ moon day (the darkest days), there is a series of successive peaks almost every other day. Thus, the most vulnerable species are mainly captured during the dark period of the cycle. During the light period the impact is minimum, with the exception of the full moon ( 1 or 2 days), when there is something like an explosion of captures.

The effect of the moon on the second group of habitats (mud, sublittoral mixed sediments and the vicinity of moderate energy circalittoral rocks) is very different. In this case, the equidistance between the peaks, which occurs each 5 or 6 days, is the salient feature. A this pattern is characteristic only of the deep-sea mud habitat, the most abundant group, with 196 hauls.

The taxonomical composition of cartilaginous fish in both groups of habitats is different, so these patterns have to be related to the biology of their respective species. However, the analysis of the species involved in the peaks of impact did not allow any conclusion to be reached.

There are many studies showing a significant relationship between behavioural patterns in marine animals and the moon phase. In fishes, one of the bestknown examples of lunar periodicity could be that of the Californian grunion (Leuresthes tenuis), whose eggs spawn only on three or four nights after a full or new moon. Lunar rhythms in commercial fisheries have also been widely reported (e.g. Moore 1958, Wilson et al. 2010). Commercial trawl fishermen in northeastern New Zealand believe that at certain phases of the moon fish are more abundant, or at least more easily caught (McDowall 1969), and personal communication from local fishermen confirmed this close relationship between the abundance of the catch of different species and the phase of the moon. They even explained to us different patterns of influence on different species, including some cartilaginous fish, clarifying that this relationship seems to persist even on cloudy days. There are also some studies showing a significant relationship between the behaviour of some species of cartilaginous fish and the moon phase. Attacks on surfers in Recife (Brazil), for example, are much more common during new and full moons than during first and last quarters (Hazin et al. 2008). Moon phase also appears to have an important effect on shark catches in Atlantic waters (Hernandez-Milian et al. 2008) in the Pacific (Pallares and Garcia-Mamolar 1985, Bigelow et al. 1999) and the Mediterranean (Damalas et al. 2007). While most of these studies analyse the effect of the different phases 
of the moon on individual species, our results show that the effect of the moon can (1) be even at a day scale, (2) affect groups of species from the same taxonomical group, and (3) be related to other factors such as the kind of habitat. Further research should be conducted in order to clarify the origin of these patterns.

A report made to the European Commission on Sensitive and Essential fish habitats in the Mediterranean Sea (European Commission 2006) establishes that there is a need for the identification and mapping of marine habitats crucial for the conservation of commercial fish in the Mediterranean Sea. This is even more important with the implementation of the European Marine Strategy Framework Directive, which mandates to incorporate potential environmental drivers and any other ecosystem knowledge into fisheries assessment and scientific advice. The present research makes it possible to determine which areas are considered to be more important in terms of protection. Moreover, it specifically takes into account the vulnerability of the local populations and how local abundance and distribution of this sensitive species can be linked to the environment and some particular sensitive areas.

These results may therefore be helpful for fisheries management. Obtaining a global index of impact based on the relative vulnerability of each species, moreover, has allowed conclusions to be reached for a whole taxonomical group. The independent analysis of species could lead to conflicting advice, which would make it much more difficult to apply for fisheries management. Thus, both the global index of impact based on the relative vulnerability of the local population of each species and the machine learning approach constitute a suitable methodological advance for the identification of marine habitats considered crucial for conservation. Machine learning, and more specifically regression and classification trees, have been scarcely used in fisheries (e.g. Mendoza et al. 2010, 2011, Pérez-Ortiz et al. 2013). However, this approach has shown a clear advantage over traditional multivariate methods or GLM/ GAM approaches, mainly because the resulting trees are by themselves explicative models of the relationship between the predictors and the response.

\section{ACKNOWLEDGEMENTS}

We thank Raul Vilela for his help with the implementation of the GIS software. Manuel Mendoza was contracted within the MariFish-European Network BADMINTON project (Bycatch and Discards: management indicators, trends, and location; http://83.212.243.10/ badminton.html). The BADMINTON project was funded by the Spanish Ministry of Science and Innovation under the subprogramme Euroinvestigation Ref: EUI 2009-04022.

\section{REFERENCES}

Baum J.K., Myers R.A., Kehler D.G., Worm B., Harley S.J., Doherty P.A. 2003. Collapse and conservation of shark populations in the Northwest Atlantic. Science 299: 389-392. http://dx.doi.org/10.1126/science.1079777

Bigelow K.A., Boggs C.H., He X. 1999. Environmental effects on swordfish and blue shark catch rates in the US North Pacific longline fishery. Fish. Oceanogr. 8: 178-198. http://dx.doi.org/10.1046/j.1365-2419.1999.00105.x

Borregaard M.K., Rahbek, C. 2010. Causality of the relationship between geographic distribution and species abundance. Quart. Rev. Biol. 85: 3-25. http://dx.doi.org/10.1086/650265

Casey J.M. Myers R.A. 1998. Near extinction of a large, widely distributed fish. Science 281: 690-692. http://dx.doi.org/10.1126/science.281.5377.690

Castro J.I., Woodley C.M., Brudek, R.L. 1999. A preliminary evaluation of the status of shark species. FAO Fisheries Technical Paper 380 .

Castro W.L., Pitcher T.J., Pauly, D. 2005. A fuzzy logic expert system to estimate intrinsic extinction vulnerability of marine fishes to fishing. Biol. Conserv. 124: 97-111. http://dx.doi.org/10.1016/j.biocon.2005.01.017

Damalas D., Megalofonou P., Apostolopoulou, M. 2007.Environmental, spatial, temporal and operational effects on swordfish (Xiphias gladius) catch rates of eastern Mediterranean Sea longline fisheries. Fish. Res. 84: 233-246. http://dx.doi.org/10.1016/j.fishres.2006.11.001

Davidson A.D., Boyer A.G., Ki H., Pompa-Mansilla S., Hamilton M.J., Costa D.P., Ceballos G., Brown J.H. 2012. Drivers and hotspots of extinction risk in marine mammals. PNAS 109: 3395-3400.

http://dx.doi.org/10.1073/pnas.1121469109

Davies C.E., Moss D., O’Hill, M. 2004. EUNIS habitat classification Revised 2004. European Environment Agency, European topic centre on nature protection and biodiversity. http://eunis.eea.europa.eu/upload/EUNIS_2004_report.pdf

Dulvy N.K., Forrest R.E. 2010. Life histories, population dynamics and extinction risks in chondrichthyans. In: Carrier J., Musick J., Heithaus M. (eds), Sharks and their Relatives II. Biodiversity, Adaptive Physiological Conservation. CRC Press, Boca Raton, pp. 639-679. http://dx.doi.org/10.1201/9781420080483-c17

Dulvy N.K., Reynolds J.D. 2002. Predicting extinction vulnerability in skates. Conserv. Biol. 16: 440-450. http://dx.doi.org/10.1046/j.1523-1739.2002.00416.x

Dulvy N.K., Sadovy Y., Reynolds J.D. 2003. Extinction vulnerability in marine populations. Fish. Fish. 4: 25-64. http://dx.doi.org/10.1046/j.1467-2979.2003.00105.x

Dulvy N.K., Ellis J.R., Goodwin N.B., Grant A., Reynolds J.D., Jennings S. 2004. Methods of assessing extinction risk in marine fishes. Fish. Fish. 5: 255-276. http://dx.doi.org/10.1111/j.1467-2679.2004.00158.x

European Commission 2006. Sensitive and Essential Fish Habitats in the Mediterranean Sea. Rome, pp. 6-10.

Ferretti F., Myers R.A., Serena F., Lotze, H.K. 2008. Loss of large predatory sharks from the Mediterranean Sea. Conserv. Biol. 22: $952-964$

http://dx.doi.org/10.1111/j.1523-1739.2008.00938.x

Frankham R., Ballou J.D., Briscoe D.A. 2002. Introduction to conservation genetics. Cambridge Univ. Press. http://dx.doi.org/10.1017/CBO9780511808999

Frisk M.G., Miller T.J., Dulvy N.K. 2005. Life histories and vulnerability to exploitation of cartilaginous fish: Inferences from elasticity, perturbation and phylogenetic analyses. J. Northw. Atl. Fish. Sci. 35: 27-45. http://dx.doi.org/10.2960/J.v35.m514

Froese R., Pauly D. 2011. FishBase. World Wide Web electronic publication. www.fishbase.org, version.

Gouraguine A., Hidalgo M., Moranta J., Bailey D., Ordines F., Guijarro B., Valls M., Barberá C., De Mesa A. 2011. Cartilaginous fish spatial segregation in the western Mediterranean. Sci. Mar. 75: 653-664. http://dx.doi.org/10.3989/scimar.2011.75n4653

Grubinger T., Zeileis A., Pfeiffer K.P. 2011. evtree: Evolutionary Learning of Globally Optimal Classification and Regression Trees. In: Working Paper 2011-xx. Working Papers in Economics and Statistics, Research Platform Empirical and Experimental Economics, Universitt Innsbruck. http://EconPapers.RePEc.org/RePEc:inn:wpaper:2011-xx

Hazin F., Burgess G., Carvalho F. 2008. A Shark Attack Outbreak Off Recife, Pernambuco, Brazil: 1992-2006. B. Mar. Sci. 82: 199-212.

Hergstrom K., Niall R. 1990. Presence-absence sampling of two spotted spider mite (Acari: Tetranychidae) in pear orchards. J. Econ. Entomol. 83: 2032-2035. 
Hernandez-Milian G., Goetz S., Varela C., Rodriguez J., Romon J., Fuertes J.R., Ulloa E., Tregenza N.J.C., Smerdon A., Otero M.G., Tato V., Wang J., Santos M.B., López A., Lago R., Portela, J., Pierce G.J. 2008. Results of a short study of interactions of cetaceans and longline fisheries in Atlantic waters: environmental correlates of catches and depredation events. Hydrobiologia 612: 251-268. http://dx.doi.org/10.1007/s10750-008-9501-2

Isaac N.J.B., Cowlishaw G. 2004. How species respond to multiple extinction threats. P. Royal Soc. B-Biol. Sci. 271: 1135-1141.

Jennings S., Kaiser M. 1998. The effects of fishing on marine ecosystems. Adv. Mar. Biol. 34: 201-352. http://dx.doi.org/10.1016/S0065-2881(08)60212-6

Jennings S., Greenstreet S.P.R., Reynolds J.D. 1999. Structural change in an exploited fish community: a consequence of differential fishing effects on species with contrasting life histories. J. Anim. Ecol. 68: 617-627. http://dx.doi.org/10.1046/j.1365-2656.1999.00312.x

Kaiser M.J., Collie J.S., Hall S.J., Jennings S. Poiner I.R. 2003. Impacts of fishing gear on marine benthic habitats. In: Sinclair M., Valdimarsson G. (eds), Respons. Fish. Mar. Ecos. pp. 197-217. Rome, FAO.

Krzysztof J.C., Pedrycz W., Swiniarski R.W., Kurgan L.A. 2007. Data Mining: A Knowledge Discovery Approach. SpringerVerlag New York, Inc. Secaucus, New Jersey.

Madsen N. 2007. Selectivity of fishing gears used in the Baltic Sea cod fishery. Rev Fish. Biol. Fish. 4: 517-544. http://dx.doi.org/10.1007/s11160-007-9053-y

Massutí E., Moranta J. 2003. Demersal assemblages and depth distribution ofcartilaginous fish from the continental shelf and slope off the Balearic Islands westernMediterranean. - ICES J. Mar. Sci. 60: 753-766. http://dx.doi.org/10.1016/S1054-3139(03)00089-4

McDowall R.M. 1969. Lunar Rhythms in Aquatic Animals: A General Review. Tuatara 17: 3

McEachran J.D., Musick J.A. 1975. Distribution and relative abundance of seven species of skates Pisces: Rajidae which occur between Nova Scotia and Cape Hatteras.U.S. Fish. B. 73: 110-136.

Mendoza M. 2007. Decision Trees: a Machine Learning Methodology for characterizing Morphological Patterns resulting from Ecological Adaptations. In: MacLeod N. (ed), Automated Object Identification in Systematics: Theory, Approaches and Applications pp. 261-276. Systematics Association's Special Volume Series, UK. http://dx.doi.org/10.1201/9781420008074.ch15

Mendoza M., García T., Baro J. 2010. Using classification trees to study the effects of fisheries management plans on the yield of Merluccius merluccius Linnaeus, 1758 in the Alboran Sea Western Mediterranean. Fish. Res.102: 191-198. http://dx.doi.org/10.1016/j.fishres.2009.11.012

Mendoza M., Pennino M.G., Bellido J.M. 2011. Tree-Based Machine Learning Analysis for Fisheries Research. In: Intilli J.S. (ed), Fishery Management pp. 25-35. Fish, Fishing and Fisheries Series. Nova Science Publishers.

Millsap B.A., Gore. J.A., Runde D.E., Cerulean S.I. 1990. Setting priorities for the conservation of fish and wildlife species in Florida. Wildlife Monographs.

Moore H.B. 1958. Marine Ecology Wiley, New York.

Nielsen S.E., Johnson C.J., Heard D.C.Boyce M.S. 2005. Can models of presence-absence be used to scale abundance? Two case studies considering extremes in life history. Ecography 28: 197-208.

http://dx.doi.org/10.1111/j.0906-7590.2005.04002.x

Pallares P., Garcia-Mamolar J.M. 1985. Efectos de las fases de la luna sobre los rendimientos de la flota atunera tropical espaola. International Commission for the Conservation of Atlantic Tunas ICCAT 23: 228-236.

Pauly D., Christensen V., Guénette S., Pitcher T., Sumaila U.R., Walters C., Watson R., Zeller D. 2002. Toward sustainability in world fisheries. Nature 418: 689-695. http://dx.doi.org/10.1038/nature01017

Pauly D., Alder J., Bennett E., Christensen V., Tyedmers P., Watson R. 2003. The future for fisheries. Science 302: 1359-1361. http://dx.doi.org/10.1126/science. 1088667

Pennino M., Mu-oz F., Conesa D., López-Quílez A.Bellido J.M. 2013. Modelling sensitive cartilaginous fish habitats. J. Sea Res. V: $1-25$.

Pérez-Ortiz M, Colmenarejo R., Fernández-Caballero J. C., HervásMartínez C. 2013. Can Machine Learning Techniques Help to Improve the Common Fisheries Policy? IWANN (2) 2013: 278-286.

Quinlan J.R. 1985. Induction of decision trees. Mach. Learn. 1: 81-106. http://dx.doi.org/10.1007/BF00116251 http://dx.doi.org/10.1023/A:1022643204877

Reynolds J.D., Jenings S., Dulvy N.K. 2001. Life histories of fishes and population responses to exploitation. In: Reynolds J.D., Mace G.M., Redford K.H., Robinson J.G. (eds), Conservation of Exploited Species pp. 147-168. Cambridge University Press, Cambridge.

Roel B.A. 1987. Demersal communities of the west coast of South Africa. South Afric. J. Mar. Sci. 5: 575-584. http://dx.doi.org/10.2989/025776187784522135

Rogan J., Franklin J., Stow D., Miller J., Roberts D.A., Woodcock C. 2008. Mapping land cover modifications over large areas: A comparison of machine learning techniques, Remote Sens. Environ. 112: 2272-2283 http://dx.doi.org/10.1016/j.rse.2007.10.004

Sadovy Y., Cheung W.L. 2003. Near extinction of a highly fecund fish: the one that nearly got away. Fish. Fish. 4: 86-99. http://dx.doi.org/10.1046/j.1467-2979.2003.00104.x

Stevens J.D., Bonfil R., Dulvy N.K., Walker P.A. 2000. The effects of fishing on sharks, rays, and chimaeras (chondrichthyans), and the implications for marine ecosystems. ICES J. Mar. Sci. 57: 476-494.

http://dx.doi.org/10.1006/jmsc.2000.0724

Venier L.A., Fahrig L. 1998. Intraspecific abundance-distribution relationships. Oikos 82: 483-490. http://dx.doi.org/10.2307/3546369

Watling L., Norse E.A. 1998. Disturbance of the seabed by mobile fishing gear: comparison to forest clearcutting. Conserv. Biol. 12: 1180-1197. http://dx.doi.org/10.1046/j.1523-1739.1998.0120061180.x

Wilson S.K., Fisher R., Pratchett M.S., Graham N.A.J., Dulvy N.K., Turner R.A., Cakacaka A., Polunin N.V.C. 2010. Habitat degradation and fishing effects on the size structure of coral reef fish communities. Ecol. Appl. 20: 442-451. http://dx.doi.org/10.1890/08-2205.1 